\title{
SEKOLAH MENENGAH PERTAMA INKLUSI DI KOTA PONTIANAK
}

\author{
Aulia Mustika Ratu' ${ }^{1}$, Muhammad Ridha Alhamdani ${ }^{2}$, Rudiyono $^{3}$ \\ ${ }^{1}$ Mahasiswa, Jurusan Arsitektur, Fakultas Teknik, Universitas Tanjungpura. \\ auliamustika02@gmail.com \\ ${ }^{2}$ Jurusan Arsitektur, Fakultas Teknik, Universitas Tanjungpura \\ ${ }^{3}$ Jurusan Arsitektur, Fakultas Teknik, Universitas Tanjungpura
}

Naskah diajukan pada: 11 Agustus 2021

Naskah revisi akhir diterima pada: 15 Agustus 2021

\begin{abstract}
Abstrak
Indonesia merupakan negara yang memperhatikan pendidikan generasi mudanya. Satuan pendidikan sekolah memegang peranan sangat penting bagi pendidikan anak. Indonesia telah memiliki program berupa Kabupaten/Kota Layak Anak (KLA). KLA adalah kabupaten/kota dengan sistem pembangunan yang menjamin pemenuhan hak anak dan perlindungan khusus anak yang dilakukan secara terencana, menyeluruh, dan berkelanjutan untuk mencapai Indonesia Layak Anak (IDOLA) diharapkan tercapai pada tahun 2030. Kota Pontianak ditetapkan sebagai Kota Layak Anak (KLA) di tingkat pertama sejak tahun 2017 yang selanjutnya naik peringkat menjadi Madya. Berkenaan dengan hal tersebut Pemerintah Kota Pontianak menjalankan program Sekolah Ramah Anak guna mewujudkan pemenuhan hak dan perlindungan anak selama 8 jam anak berada di sekolah serta memfasilitasi kebutuhan pendidikan yang merata bagi semua kalangan anak, baik yang berkebutuhan khusus, serta difabel dihadirkan dalam bentuk Sekolah Menengah Pertama Inklusi. Metode perancangan Sekolah Menengah Inklusi yang digunakan yaitu tahap gagasan, tahap pengumpulan data, tahap analisis, tahap sintesis, dan tahap perancangan. Program yang digunakan dalam perancangan Sekolah Menengah Pertama Inklusi ialah Sekolah Ramah Anak (SRA). Perancangan ini menghasilkan desain sekolah dengan pendekatan ramah anak dengan menerapkan filosofi "Dibalik Kekurangan Terdapat Kelebihan". Hal ini ditunjukkan dengan fasilitas yang mewadahi kegiatan di sekolah, baik secara makro maupun mikro.
\end{abstract}

Kata-kata Kunci: Kota Layak Anak, Sekolah Menengah Pertama Inklusi, Sekolah Ramah Anak

\begin{abstract}
Indonesia is a country that pays attention to the education of its young generation. The school education unit plays a very important role in the education of children. Indonesia already has a program in the form of Child-Friendly Districts/Cities (KLA). KLA is a district/city with a development system that guarantees the fulfillment of children's rights and special protection for children that is carried out in a planned, comprehensive, and sustainable manner to achieve Child-friendly Indonesia (IDOLA) which is expected to be achieved in 2030. Pontianak city crowned as a Child Friendly City (KLA) at the first level since 2017 which subsequently up to become Madya. In this regard, the Pontianak City Government runs the Child Friendly School program as effort to realize the fulfillment of children's rights and protection for 8 hours of children being in school, and also the aim of being a forum that facilitates equitable educational needs for all children, both those with special needs, and with disabilities that presented in the form of Inclusive Junior High Schools. The Inclusive School design method used the idea stage, the data collection stage, the analysis stage, the synthesis stage, and the design stage. The program used in the design of the Inclusive Junior High School is the ChildFriendly School (SRA). The result is a child-friendly inclusive school design by applying the philosophy of "Behind Weaknesses There Are Advantages". This is indicated by the facilities that accommodate activities in schools, both macro, and micro.
\end{abstract}

Keywords: Child-Friendly City, Inclusive Junior High School, Child-Friendly School 


\section{Pendahuluan}

Generasi muda Indonesia merupakan harapan bagi bangsa Indonesia. Karena generasi muda yang memegang ujung tombak kemajuan sebuah bangsa. Setiap anak, baik laki - laki maupun perempuan berhak mendapatkan pendidikan yang layak. Agar anak anak dapat belajar dengan baik, sekolah harus mampu menyediakan fasilitas yang baik pula seperti sarana dan prasarana yang sesuai dengan kebutuhan anak, dan dapat menciptakan suasana lingkungan yang aman dan nyaman bagi anak. Berdasarkan data dari Kementerian Pendidikan Republik Indonesia, jumlah anak berkebutuhan khusus di Indonesia sekitar 1,6 juta jiwa. Berdasarkan total anak berkebutuhan khusus tersebut, hanya ada sekitar $18 \%$ anak yang sudah mendapatkan layanan pendidikan inklusi, di antaranya sekitar 115.000 anak bersekolah di SLB sedangkan sekitar 299.000 anak lainnya bersekolah di sekolah reguler pelaksana sekolah inklusi (Pusat Data dan Statistik Pendidikan dan Kebudayaan Kemendikbud RI, 2016).

Kota Pontianak ditetapkan sebagai Kota Layak Anak (KLA) di tingkat pertama selama tiga tahun berturut-turut, program yang sudah dilaksanakan sejak tahun 2017 yang selanjutnya naik peringkat menjadi Madya. Disdikbud Kota Pontianak bersama dengan Dinas Pengendalian Penduduk, Keluarga Berencana, Pemberdayaan Perempuan, dan Perlindungan Anak (DP2KBP3A) saling bersinergi untuk menciptakan Sekolah Ramah Anak di seluruh Kota Pontianak. Agar program Pemerintah Kota Pontianak tentang Sekolah Ramah Anak yang dapat menjadikan Kota Pontianak sebagai Kota Layak Anak, penulis bermaksud untuk merencanakan sebuah sekolah yang bisa menyinergikan semua program agar anak mendapatkan kesamaan perlakuan pendidikan maka direncakan sebuah sekolah inklusi di Kota Pontianak.

Sekolah Inklusi ini akan dirancang sebagai lembaga milik negara negara menyoroti hal ini dikarenakan Kota Pontianak sendiri telah memiliki program ramah anak dan menunjuk beberapa sekolah pada tahun 2020 untuk menjalankan program sekolah tersebut. Tetapi program tersebut belum berjalan dikarenakan Surat Keputusan belum dikeluarkan, karena beberapa hal salah satunya fasilitas yang belum memadai. Adanya sekolah ini dengan tujuan sebagai wadah yang mengoptimalkan fasilitas pendidikan Sekolah Menengah Pertama Inklusi sebagai sekolah yang ramah anak. Hasil rancangan diharapkan dapat mengakomodasi siswa untuk melatih diri dan mengembangkan diri siswa, serta menciptakan konsep ruangan yang baik bagi para siswa Sekolah Menengah Pertama Inklusi agar merasa senang di sekolah.

\section{Kajian Pustaka}

Sekolah sebagai fasilitas pendidikan diharapkan dapat menjadi wadah proses pembelajaran untuk meningkatkan kualitas output atau keluaran bagi siswa didik dan pendidiknya. Tugas perencana tidak hanya melihat pada aspek fungsional, namun dapat melihat hal mendasar lainnya yang mempengaruhi perkembangan dan proses pembelajaran di sekolah (Hatmoko; dkk, 2014).

Sekolah Inklusi adalah sekolah reguler yang mengkoordinasi dan mengintegrasikan siswa reguler dan siswa berkebutuhan khusus dalam program yang sama. Pendidikan inklusi merupakan sebuah pendekatan yang berusaha mentransformasikan sistem pendidikan dengan meniadakan hambatan-hambatan yang dapat menghalangi setiap siswa untuk berpartisipasi penuh dalam pendidikan (Ramadhani, 2017).

Anak berkebutuhan khusus diklasifikasikan menjadi anak disabilitas penglihatan, anak disabilitas pendengaran, anak disabilitas intelektual, anak disabilitas fisik, anak disabilitas sosial, anak dengan gangguan pemusatan perhatian dan hiperaktivitas (GPPH), anak dengan gangguan spektrum autisma atau autism spectrum disorders (ASD), anak dengan gangguan ganda, Anak lamban belajar atau slow learner, anak dengan kesulitan belajar khusus atau specific learning disabilities, anak dengan gangguan kemampuan komunikasi, dan Anak dengan potensi kecerdasan dan/atau bakat istimewa. Adapun yang masih bisa diterima di SMP Inklusi ialah anak disabilitas 
penglihatan sebagian dan low vision, anak disabilitas pendengaran dengan pendengaran (27-40 dB dan $41-55 \mathrm{~dB}$ ), anak disabilitas intelektual dengan IQ $51-70 \mathrm{~dB}$, dan anak disabilitas lainnya.

Jenis terapi yang dibutuhkan anak berkebutuhan khusus di SMP Inklusi di Kota Pontianak meliputi terapi okupasi, terapi wicara, fisioterapi, terapi edukatif, dan terapi perilaku. Kurikulum yang digunakan pada SMP Inklusi ialah kurikulum standar nasional yang telah disesuaikan dengan kebutuhan, bakat, dan potensi siswa. Pembelajaran inklusif, model kurikulum bagi siswa berkebutuhan khusus dikelompokkan menjadi empat, yaitu: Duplikasi kurikulum, modifikasi kurikulum, substitusi kurikulum, dan omisi kurikulum (Tarmansyah, 2007).

\section{Metode}

Perancangan Sekolah Menengah Pertama Inklusi menggunakan metode desain oleh Jones (1992) terdiri dari penetapan masalah, pendataan lapangan, literatur, tipologi, analisis pemrograman, sintesis, skematik desain, penyusunan konsep dan perwujudan desain. Metode pengumpulan data dan analisis data. Metode pengumpulan data terbagi menjadi data primer dan data sekunder, keduanya dengan metode kualitatif dalam bentuk observasi lapangan, wawancara melibatkan masyarakat, dan studi literatur. Selanjutnya metode penyusunan dan analisis, dijabarkan metode perancangan yang terdapat tahap sintesis, dan tahap perancangan.

Tahapan analisis mencakup analisis fungsi tema perancangan,internal, eksternal, bentuk, struktur, utilitas, serta fisika bangunan. Setelah dilakukan sintesis atau analisis selanjutnya menarik konsep yang terdiri dari konsep fungsi tema perancangan, internal, eksternal, bentuk, struktur, utilitas, serta fisika bangunan. Kemudian desain akhir berupa perancangan detail mengenai sekolah inklusi seperti adanya perencanaan gambar kerja yang meliputi denah, tampak, potongan, dan lainnya.

\section{Hasil dan Pembahasan}

Hasil dan pembahasan berisi sintesis/analisis yang menghasilkan konsep perancangan Sekolah Menengah Pertama Inklusi. Analisis berisi analisis pemilihan lokasi, fungsi dan tema, internal, eksternal, bentuk, struktur serta utilitas. Selanjutnya konsep mengenai hasil analisis dan hasil perancangan dari Sekolah Menengah Pertama Inklusi di Kota Pontianak.

\section{Lokasi Perancangan}

Lokasi perancangan Sekolah Menengah Pertama Inklusi berada di Jalan Sepakat 1, Kecamatan Pontianak Tenggara, Kota Pontianak. Analisis pemilihan lokasi berdasarkan pada SNI Tata Cara Perencanaan Lingkungan Perumahan di Perkotaan Tahun 2004 yaitu lokasi dapat dijangkau dengan kendaraan umum, serta berdasarkan hasil analisis kebutuhan fasilitas pendidikan SMP di Pontianak, bahwa Kecamatan Pontianak Tenggara membutuhkan fasilitas SMP negeri. Berdasarkan data ukuran dan tata wilayah luas lahan 2,6 hektar, keliling Lahan $\quad 697,6 \mathrm{~m}$, status wilayah berupa tanah kosong, lebar Jalan Sepakat 1 selebar 8 m, lebar parit selebar 7 m, KDB 60\%, KDH $\quad 40 \%$, GSB sebesar 2/5 dari Ruang Milik Jalan, KLB 2,4.

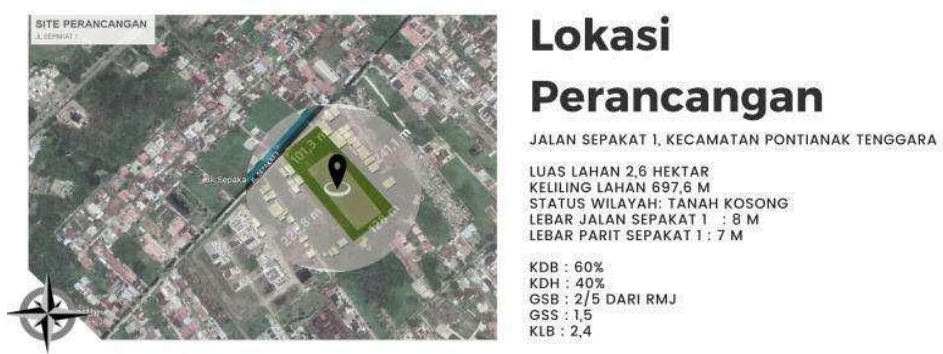

Gambar 1. Lokasi Perancangan

Sumber: Penulis, 2021 


\section{Landasan Konseptual}

Fungsi perancangan SMP Inklusi terbagi menjadi tiga kelompok fungsi yaitu fungsi primer, fungsi sekunder, dan fungsi tersier. Fungsi utama Sekolah Menengah Pertama Inklusi ialah sebagai fungsi paling prioritas dan utama di dalam sekolah inklusi yaitu fasilitas pendidikan. Fungsi sekunder adalah fungsi yang mendukung kegiatan dalam sekolah inklusi seperti adanya fungsi kegiatan administrasi, fungsi pusat terapi, fungsi terapi. Fungsi tersier adalah adalah kegiatan berkenaan dengan perawatan dan servis dalam sekolah inklusi. Fungsi terdiri dari fungsi server, maintenance, istirahat, parkir, dan tempat ibadah.

Tema atau pendekatan yang digunakan pada SMP Inklusi ialah melalui program Sekolah Ramah Anak (SRA). Kemudian diterjemahkan ke dalam konsep tapak, bentuk ruang, struktur, utilitas, dan lainnya yang memiliki unsur sekolah ramah anak. Berikut alur pendekatan SMP Inklusi dengan program Sekolah Ramah Anak (SRA):

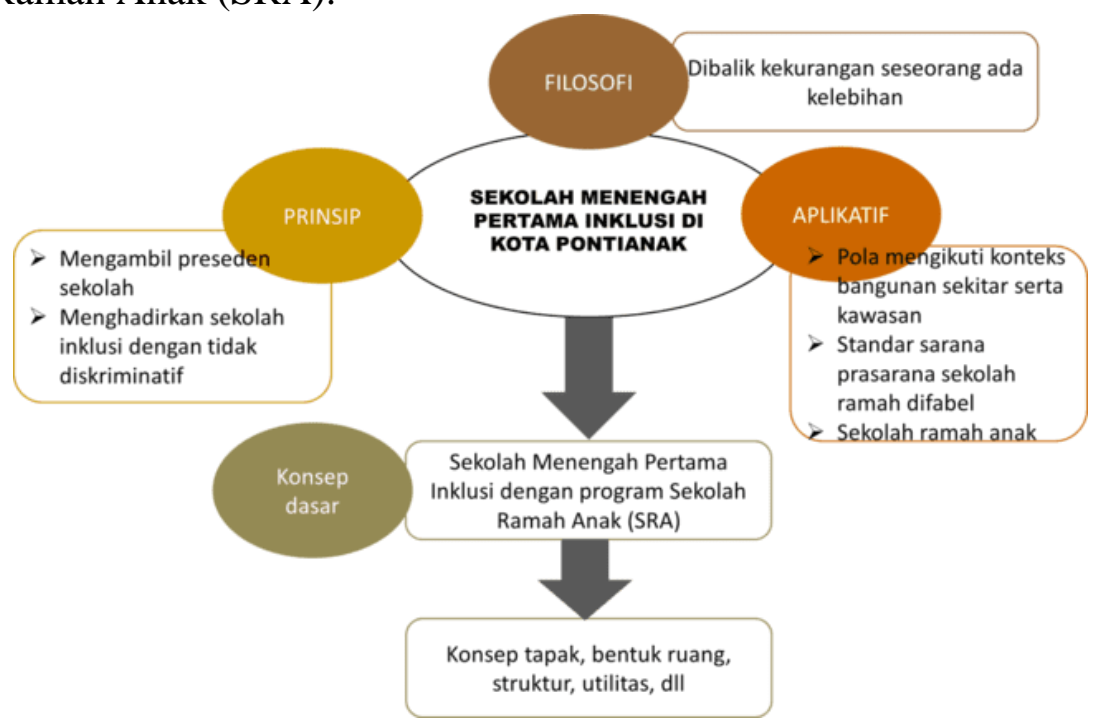

Gambar 2. Alur Konsep Tema Perancangan

Sumber: Penulis, 2021

Pelaku di Sekolah Menengah Pertama Inklusi dikelompokkan menjadi siswa siswa reguler, siswa berkebutuhan khusus, pengelola, pengunjung, dan tenant. Secara garis besar pelakunya merupakan siswa reguler dan berkebutuhan khusus dengan usia sekitar 12 tahun hingga batas maksimal 15 tahun. Adapun siswa berkebutuhan khusus yang diterima ialah mengalami hambatan penglihatan, hambatan pendengaran, hambatan komunikasi, hambatan intelektual, hambatan fisik, kesulitan belajar, Celebral palsy, Gifted, Autis ADHD ringan, Lamban belajar, hambatan emosi sosial. Peserta didik yang masih sulit untuk diterima di sekolah penyelenggara inklusi ialah yang mengalami hambatan pendengaran $100 \%$, hambatan penglihatan $100 \%$, hambatan fisik yang sertai dengan hambatan kecerdasan berat, autisme yang belum mandiri.

Kebutuhan ruang bangunan Sekolah Menengah Pertama Inklusi berjumlah 50 ruang dikelompokkan dalam beberapa zona yaitu zona pendidikan, zona pengelola, zona pusat informasi, zona terapi, zona servis, zona parkir, zona ibadah, zona istirahat. Berikut tabel program ruang:

Tabel 1. Program Ruang

\begin{tabular}{|c|c|c|c|c|c|}
\hline No & Zona & Nama Ruang & $\begin{array}{c}\text { Sifat } \\
\text { Ruang }\end{array}$ & $\begin{array}{l}\text { Jumlah } \\
\text { Ruang }\end{array}$ & $\begin{array}{c}\text { Besaran } \\
\text { Ruang }\end{array}$ \\
\hline 1 & \multirow{3}{*}{ PENDIDIKAN } & Ruang Kelas & Privat & 21 & $1344 \mathrm{~m}^{2}$ \\
\hline 2 & & Taman Belajar & Publik & 1 & $500 \mathrm{~m}^{2}$ \\
\hline 3 & & Aula & $\begin{array}{c}\text { Semi } \\
\text { Publik }\end{array}$ & 1 & $112 \mathrm{~m}^{2}$ \\
\hline
\end{tabular}




\begin{tabular}{|c|c|c|c|c|c|}
\hline 4 & & Lab Bahasa & Semi Privat & 1 & $75 \mathrm{~m}^{2}$ \\
\hline 5 & & Lab IPA & Semi Privat & 1 & $75 \mathrm{~m}^{2}$ \\
\hline 6 & & Lab Komputer & Semi Privat & 1 & $75 \mathrm{~m}^{2}$ \\
\hline 7 & & R. Seni Tari & Semi Privat & 1 & $65 \mathrm{~m}^{2}$ \\
\hline 8 & & R. Seni Vokal\&Musik & Semi Privat & 1 & $65 \mathrm{~m}^{2}$ \\
\hline 9 & & R. Seni Lukis & Semi Privat & 1 & $65 \mathrm{~m}^{2}$ \\
\hline 10 & & Perpustakaan & Publik & 1 & $96 \mathrm{~m}^{2}$ \\
\hline 11 & & R.Bermain & $\begin{array}{c}\text { Semi } \\
\text { Publik }\end{array}$ & 1 & $40 \mathrm{~m}^{2}$ \\
\hline 12 & & R. Osis & Privat & 1 & $9 \mathrm{~m}^{2}$ \\
\hline 13 & & R. Konseling & Privat & 1 & $9 \mathrm{~m}^{2}$ \\
\hline 14 & & UKS & Semi Privat & 1 & $12 \mathrm{~m}^{2}$ \\
\hline 15 & & Area Berkebun & Publik & 1 & $9 \mathrm{~m}^{2}$ \\
\hline 16 & & Lap Olahraga & Publik & 2 & $1000 \mathrm{~m}^{2}$ \\
\hline 17 & \multirow{7}{*}{$\begin{array}{l}\text { PENGELOLA/ } \\
\text { MAINTENANCE }\end{array}$} & R. Pimpinan & Privat & 1 & $18 \mathrm{~m}^{2}$ \\
\hline 18 & & R. Rapat & Privat & 1 & $12 \mathrm{~m}^{2}$ \\
\hline 19 & & R. Arsip & Privat & 1 & $12 \mathrm{~m}^{2}$ \\
\hline 20 & & $\begin{array}{l}\text { R. Administrasi/Staff } \\
\text { TU }\end{array}$ & Privat & 1 & $16 \mathrm{~m}^{2}$ \\
\hline 21 & & R. Guru & Privat & 1 & $90 \mathrm{~m}^{2}$ \\
\hline 22 & & Pos Satpam & Semi Privat & 1 & $9 \mathrm{~m}^{2}$ \\
\hline 23 & & R. CCTV & Privat & 1 & $6 \mathrm{~m}^{2}$ \\
\hline 24 & \multirow{2}{*}{ PUSAT INFORMASI } & Lobby & Publik & 1 & $120 \mathrm{~m}^{2}$ \\
\hline 25 & & R. Informasi & Publik & 1 & $9 \mathrm{~m}^{2}$ \\
\hline 26 & \multirow{7}{*}{ R.TERAPI } & R. Praktek Psikolog & Privat & 1 & $9 \mathrm{~m}^{2}$ \\
\hline 27 & & R. Terapi Okupasi & Privat & 1 & $12 \mathrm{~m}^{2}$ \\
\hline 28 & & R. Terapi Wicara & Privat & 1 & $12 \mathrm{~m}^{2}$ \\
\hline 29 & & R. Fisioterapi & Privat & 1 & $12 \mathrm{~m}^{2}$ \\
\hline 30 & & R. Terapi Edukatif & Privat & 1 & $12 \mathrm{~m}^{2}$ \\
\hline 31 & & R. Terapi Perilaku & Privat & 1 & $12 \mathrm{~m}^{2}$ \\
\hline 32 & & Taman Terapi & Publik & 1 & $500 \mathrm{~m}^{2}$ \\
\hline 33 & \multirow{10}{*}{ SERVIS } & Gudang Barang & Privat & 1 & $21 \mathrm{~m}^{2}$ \\
\hline 34 & & R. Genset & Privat & 1 & $10 \mathrm{~m}^{2}$ \\
\hline 35 & & R. Pompa \& Tandon & Privat & 1 & $30 \mathrm{~m}^{2}$ \\
\hline 36 & & R. Panel & Privat & 1 & $9 \mathrm{~m}^{2}$ \\
\hline 37 & & Dapur & Privat & 1 & $9 \mathrm{~m}^{2}$ \\
\hline 38 & & R. Janitor & Privat & 1 & $6 \mathrm{~m}^{2}$ \\
\hline 39 & & Pantry & Privat & 1 & $11,25 \mathrm{~m}^{2}$ \\
\hline 40 & & $\mathrm{WC}$ & Privat & 6 & $72 \mathrm{~m}^{2}$ \\
\hline 41 & & Tangga & Publik & 5 & $90,72 \mathrm{~m}^{2}$ \\
\hline 42 & & Ramp & Publik & 1 & $24,48 \mathrm{~m}^{2}$ \\
\hline 43 & \multirow{3}{*}{ PARKIR } & Parkir Pengelola & Publik & 1 & $635 \mathrm{~m}^{2}$ \\
\hline 44 & & Parkir Pengunjung & Publik & 1 & $995 \mathrm{~m}^{2}$ \\
\hline 45 & & Drop Off & Publik & 1 & $12 \mathrm{~m}^{2}$ \\
\hline 46 & \multirow{3}{*}{ IBADAH } & R. Sholat & Privat & 1 & $24 \mathrm{~m}^{2}$ \\
\hline 47 & & Tempat wudhu & Privat & 1 & $12 \mathrm{~m}^{2}$ \\
\hline 48 & & $\mathrm{WC}$ & Privat & 1 & $12 \mathrm{~m}^{2}$ \\
\hline
\end{tabular}




\begin{tabular}{|c|c|c|c|c|c|}
\hline \multirow{2}{*}{$\begin{array}{l}49 \\
50 \\
\end{array}$} & \multirow{2}{*}{ ISTIRAHAT } & Kantin & Publik & 1 & $270 \mathrm{~m}^{2}$ \\
\hline & & Taman & Publik & 1 & $250 \mathrm{~m}^{2}$ \\
\hline \multicolumn{5}{|c|}{ TOTAL } & $6826 \mathrm{~m}^{2}$ \\
\hline \multicolumn{5}{|c|}{ SIRKULASI $30 \%$} & $2047 \mathrm{~m}^{2}$ \\
\hline \multicolumn{3}{|r|}{ TOTAL LUASAN } & & & $8873 \mathrm{~m}^{2}$ \\
\hline
\end{tabular}

Sumber: Penulis, 2021

Total luasan besaran ruang sebesar $8.873 \mathrm{~m}^{2}$. Konsep ruang kelas ialah terdiri dari 21 rombongan belajar. Setiap angkatan terdiri dari 7 kelas yaitu dari kelas A hingga kelas G. Setiap kelas terdiri dari 32 orang siswa dengan estimasi minimal 1 dan maksimal 3 orang siswa yang berkebutuhan khusus per kelas.

Analisis eksternal bangunan berupa perletakan, orientasi, sirkulasi, vegetasi, dan zonasi. Perletakan bangunan dimundurkan untuk menjauhkan dari kebisingan jalan raya. Bagian depan dimundurkan GSB 7 m untuk sirkulasi kendaraan seperti parkiran, dan drop off sekolah. KDB 60\%, $\mathrm{KDH} 40 \%$ sehingga luas daerah yang bisa terbangun ialah sekitar 15.6 hektar, dan luas daerah hijau sekitar 10.4 hektar. Perletakan lebih ke dalam site juga agar pencapaian anak tidak langsung ke jalan raya. Area barat daya dimundurkan untuk sirkulasi entrance samping. Orientasi bangunan menghadap ke barat laut maka searah jalan utama sepakat 1, dan timur laut guna kemudahan sirkulasi serta memanfaatkan sinar matahari pagi.

Sirkulasi dibuat hampir mengelilingi bangunan agar mudah mengakses keseluruhan bagian bangunan jika terjadi bencana. Untuk mengakomodasi anak berkebutuhan khusus tuna netra, sirkulasi eskterior maupun interior dipasang guiding block untuk memudahkan mereka mengakses bangunan. Agar memudahkan tuna daksa dalam mengakses bangunan sirkulasi outdoor dibuat adanya pedestrian serta memudahkan pejalan kaki lainnya.

Vegetasi pada site, dengan menambah ruang terbuka hijau pada area parkir, vegetasi glodokan tiang pada bagian depan sebagai pagar, vegetasi palem pada area ibadah dan istirahat. Taman terapi sebagai ruang komunal yang menjadi interaksi anak berkebutuhan khusus satu dengan lainnya. Karena minimnya interaksi yang terjadi di sekolah pada umumnya. Taman terapi terdapat vegetasi yaitu vegetasi peneduh, vegetasi pengarah, dan vegetasi estetika.

Zonasi, terbagi menjadi pendidikan, pengelola, pusat informasi, terapi, servis, ibadah, istirahat, dan zona parkir. Zona pusat informasi dan parkir tergolong ke dalam zona publik berada di dekat sirkulasi utama, agar mudah di akses oleh publik. Zona pendidikan, ibadah, istirahat termasuk ke zona semi privat. Zona terapi, pengelola, temasuk zona privat.

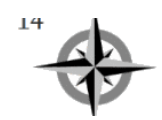

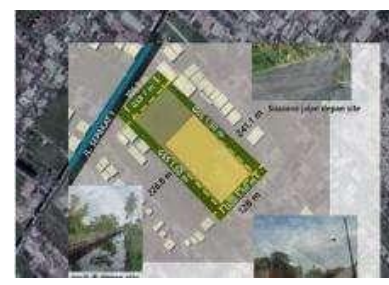

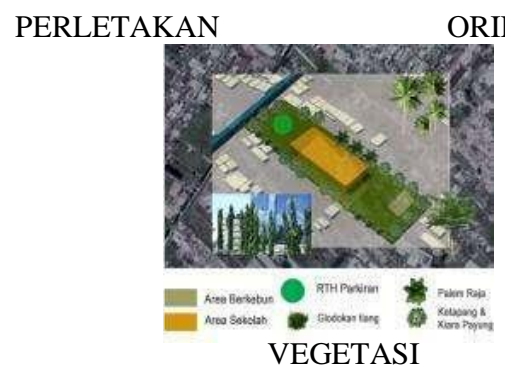

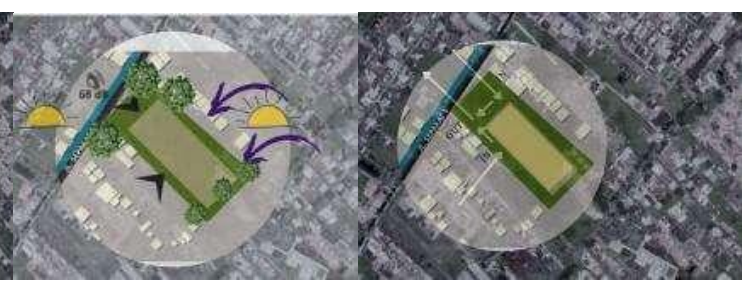

ORIENTASI

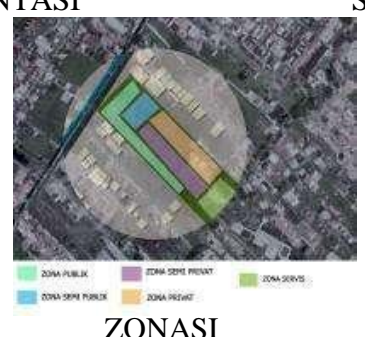

ZONASI

Gambar 3. Analisis Eksternal

Sumber: Penulis, 2021 
Konsep bentuk terbagi menjadi Form \& Spatial, Analysis \& Programming, Desain Universal, Environment control, dan Safety fire protection. Form \& Spatial, zona dipisah menjadi zona pendidikan, zona istirahat, zona servis, zona pengelola, zona terapi, zona pusat informasi, area berkebun. Bentuk bangunan menyesuaikan dengan kebutuhan ruang, serta mengambil intisari dari filosofi "Dibalik Kekurangan Terdapat Kelebihan". Analysis \& Programming, melihat kondisi tapak, desain dibuat merespon eksisting. Sisi kanan terdapat ruang kelas 9A - 9G, sisi kiri terdapat laboratorium. Koridor saling interkoneksi sehingga tiap bangunan mudah diakses. Aksesibilitas dari entrance kemudian ruang pengelola, keluar menuju taman sebagai pengikat di tengah. Desain Universal, konteks universal artinya dapat mewadahi semua jenis kalangan. Ramah anak direalisasikan dalam bentuk desain seperti adanya ramp yang mengakomodasi seluruh lantai. guiding block bagi pengguna tuna netra, dan sliding door bagi pengguna tuna daksa. Environment control, bangunan dirancang ramping agar angin dapat dengan mudah masuk ke bangunan, dilengkapi dengan cross ventilation agar terjadinya pertukaran udara masuk dan keluar. Safety fire protection, bangunan ini juga tanggap terhadap bencana, dilengkapi dengan adanya assembly point bagian luar bangunan

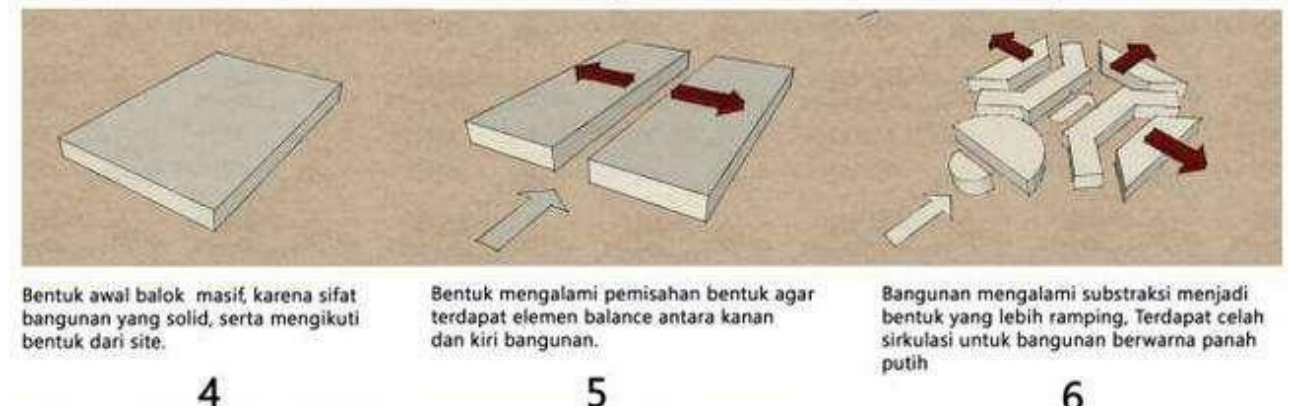

5

6

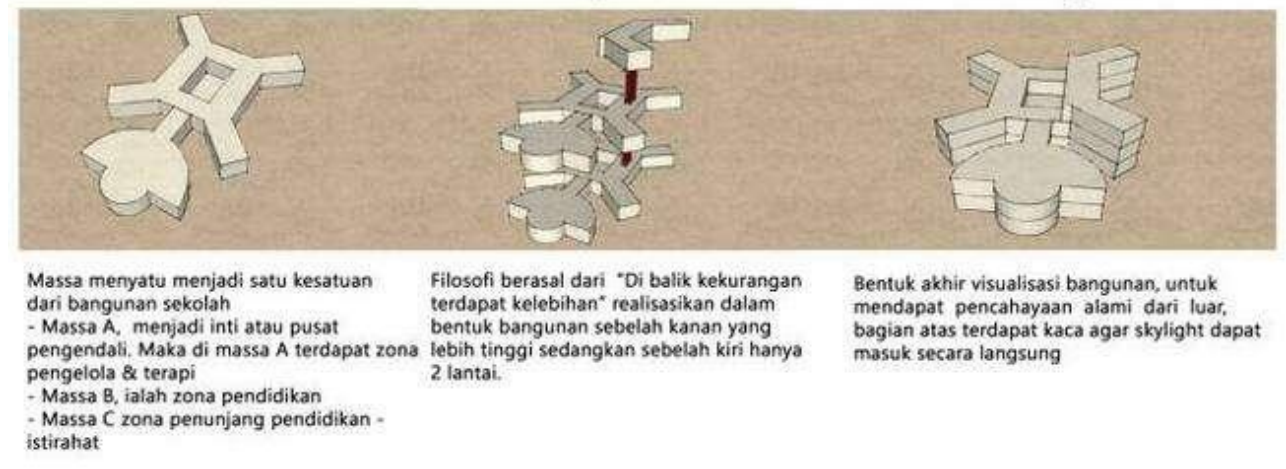

Gambar 4. Gubahan Bentuk

Sumber: Penulis, 2021

Konsep struktur terdiri dari Sub structure dan upper structure. Sub structure berupa pondasi yaitu pondasi tiang pancang beton. Upper structure terdiri dari rangka bangunan, dinding, lantai, dan atap. Rangka menggunakan sistem rigid frame atau disebut rangka kaku, terdiri dari kolom bulat berdiameter $45 \mathrm{~cm}$ material beton bertulang. Sedangkan balok berukuran 35/75 $\mathrm{cm}$ menggunakan material beton. Lantai menggunakan plat lantai tebal $20 \mathrm{~cm}$, dinding menggunakan beton ringan karena tahan api, serta kuat menahan beban. Konsep ini digunakan atas beberapa pertimbangan yaitu mengingat sekolah negeri merupakan bangunan pemerintah sehingga sesuai dengan Standar Nasional Indonesia. Pemilihan kolom berbentuk bulat agar tidak ada sudut yang berbahaya bagi anak - anak.. Pemilihan bentuk atap perisai memiliki 45 derajat agar air hujan dapat jatuh dengan cepat ke permukaan, kerangka yang digunakan ialah baja ringan karena lebih ringan, tahan rayap jika finishing, proses pemasangan mudah. 

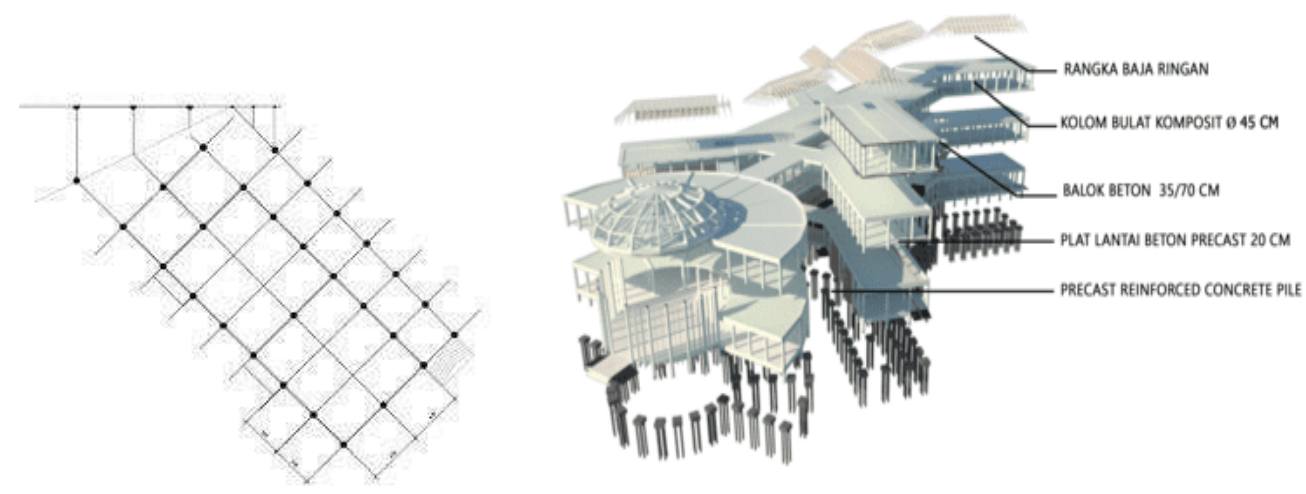

Gambar 5. Konsep Struktur

Sumber: Penulis, 2021

Konsep utilitas terdiri dari air bersih, air kotor, kotoran, transportas vertikal, dan keamanan bangunan. Konsep yang diterapkan menyesuaikan dengan standar aturan plumbing di Indonesia SNI 03-7065-2005, menggunakan 5 buah tandon untuk menyimpan air hujan. Tandon diletakkan di atas bangunan dengan sistem downfeed. Pipa primer air PDAM berasal dari arah depan kemudian akan disebar keseluruh bangunan yang membutuhkan air PDAM seperti KM/WC, Musholla, dan Pantry Kantin. Akses transportasi vertikal di sirkulasi tiap bangunan. agar seluruh bagian sekolah dapat diakses saat terjadi kejadian yang tak diinginkan seperti kebakaran, ataupun bencana alam. Berikut gambar alur air bersih, air kotor, serta titiknya.

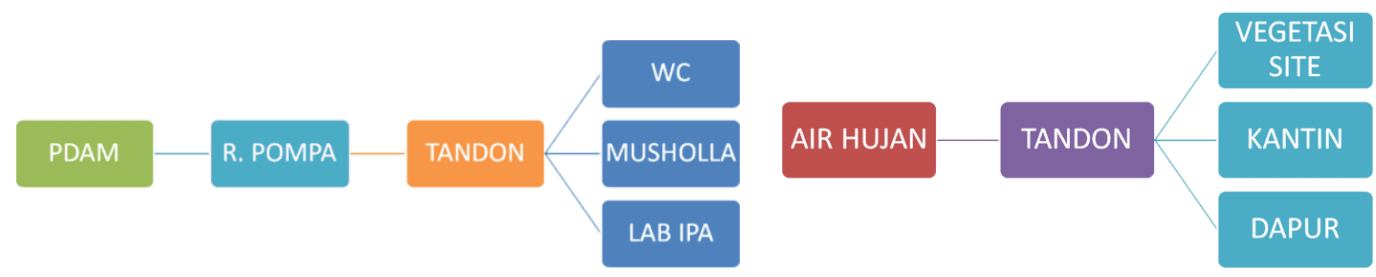

Gambar 6. Konsep Utilitas Air Bersih

Sumber: Penulis, 2021

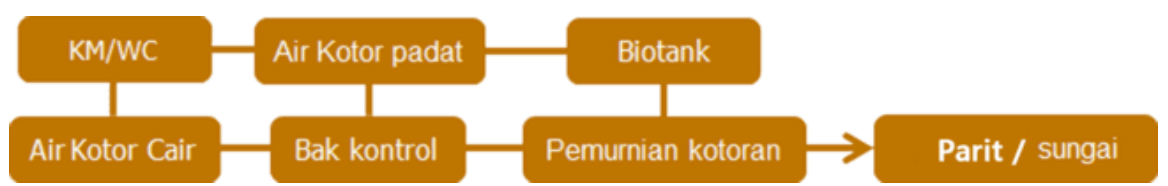

Gambar 7. Konsep Utilitas Air Bersih

Sumber: Penulis, 2021

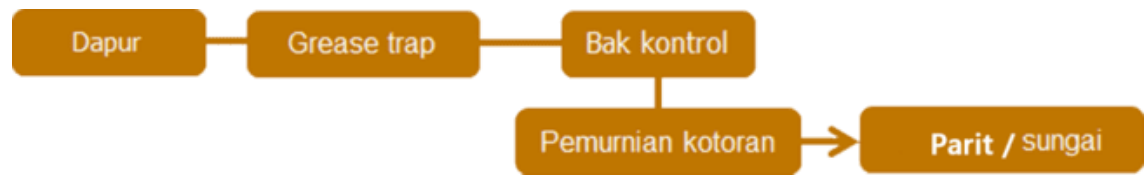

Gambar 8. Konsep Utilitas Air Bersih

Sumber: Penulis, 2021

Setiap koridor terpasang adanya speaker informasi agar informasi dapat didengar dengan mudah oleh siswa. Layar monitor pintar yang memberikan informasi terhadap sekolah inklusi serta 
sikap yang dapat dilakukan saat berada di sekolah inklusi. Disediakan wc difabel disetiap lantai yang mengakomodasi anak berkebutuhan khusus.

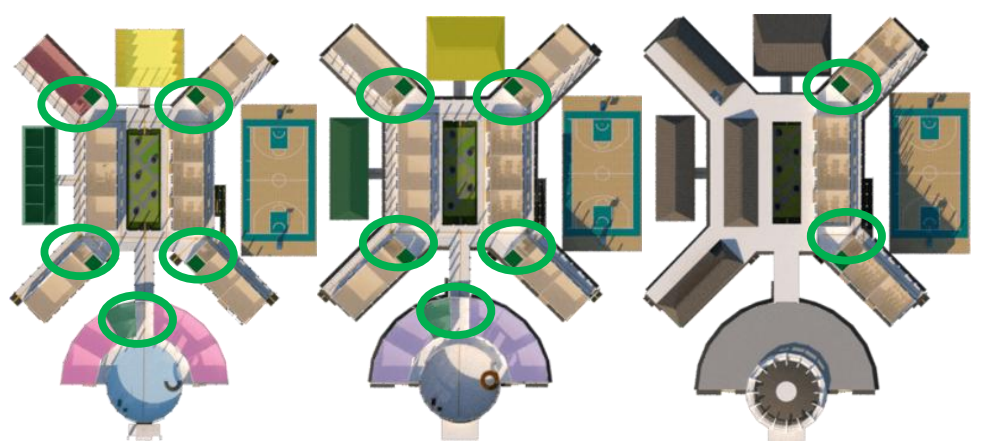

Gambar 9. Letak WC per lantai

Sumber: Penulis, 2021
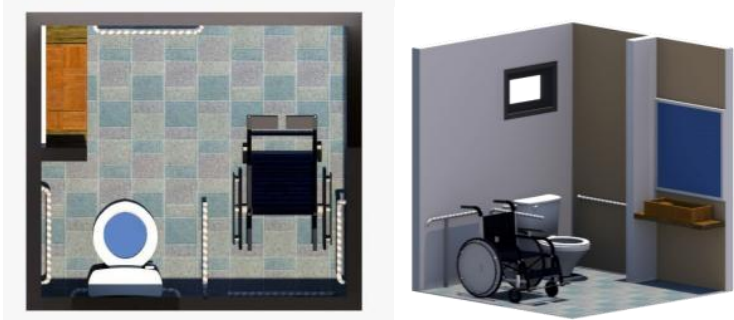

Gambar 10. WC Difabel

Sumber: Penulis, 2021

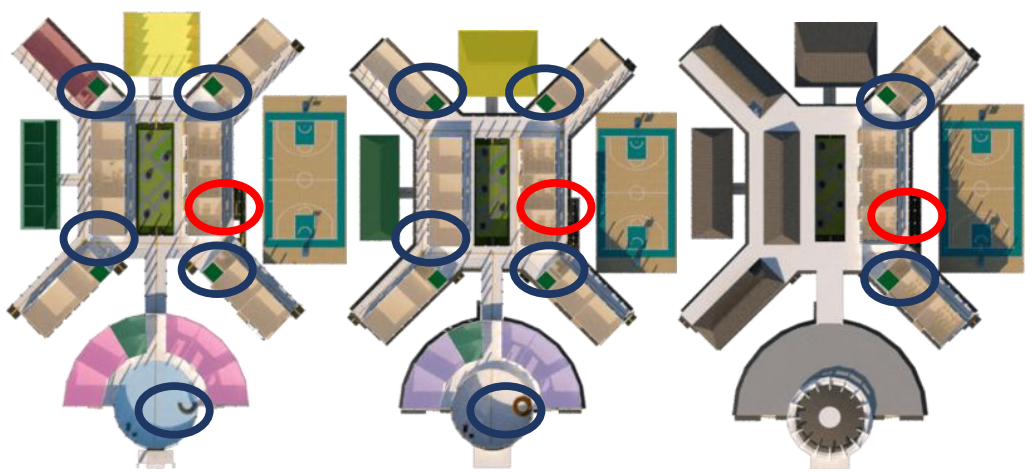

Gambar 11. Konsep Utilitas transportasi vertikal per lantai

Sumber: Penulis, 2021

\section{Hasil Perancangan}

Berdasarkan analisis dan konsep yang sudah dipaparkan, Sekolah Menengah Pertama Inklusi di Kota Pontianak merupakan sekolah negeri yang mengakomodasi anak reguler dan anak berkebutuhan khusus di SMP. Desain sekolah inklusi dengan pendekatan ramah anak dengan menerapkan filosofi "Dibalik Kekurangan Terdapat Kelebihan". Hal ini ditunjukkan dengan fasilitas yang mewadahi kegiatan di sekolah, baik secara makro maupun mikro. Secara makro dapat terlihat dari irama pada bangunan sisi kanan lebih tinggi dibanding sisi kiri bangunan. Perancangan tata ruang luar direncanakan dapat mewadahi setiap anak dari adanya pencapaian dengan pedestrian dari parkiran menuju bangunan dengan guiding block bagi pengguna tuna netra, adanya akses ramp yang aman bagi penyadang tuna daksa menggunakan kursi roda maupun tongkat. Kegiatan outdoor siswa seperti adanya area berkebun untuk bina diri siswa. Ruang terbuka berupa taman sebagai pengikat 
bangunan memberikan kolektif memori, serta menjadikan ruang komunal siswa agar siswa dapat berinteraksi satu dengan lainnya.

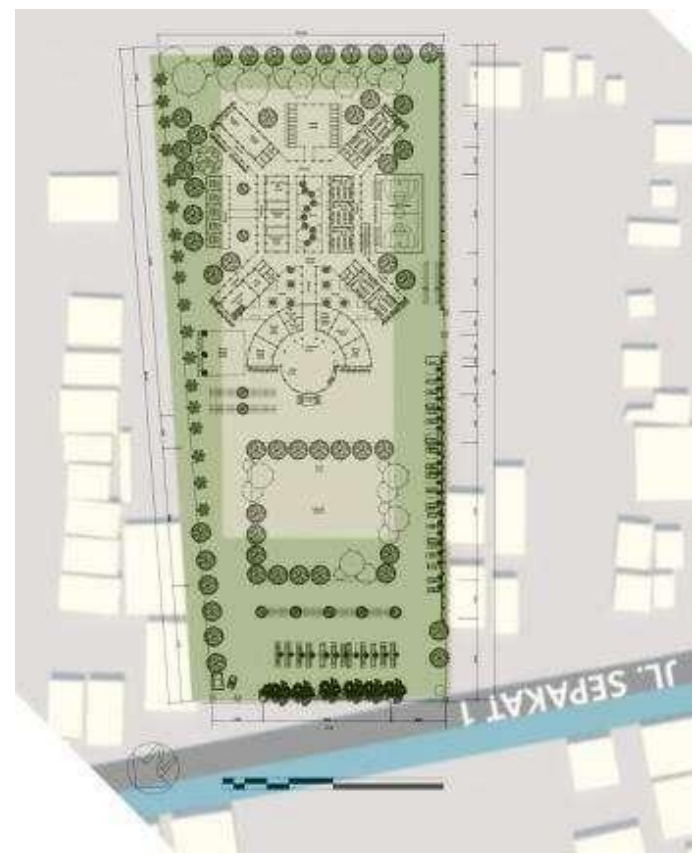

Gambar 12. Situasi plan SMP Inklusi

Sumber: Penulis, 2021

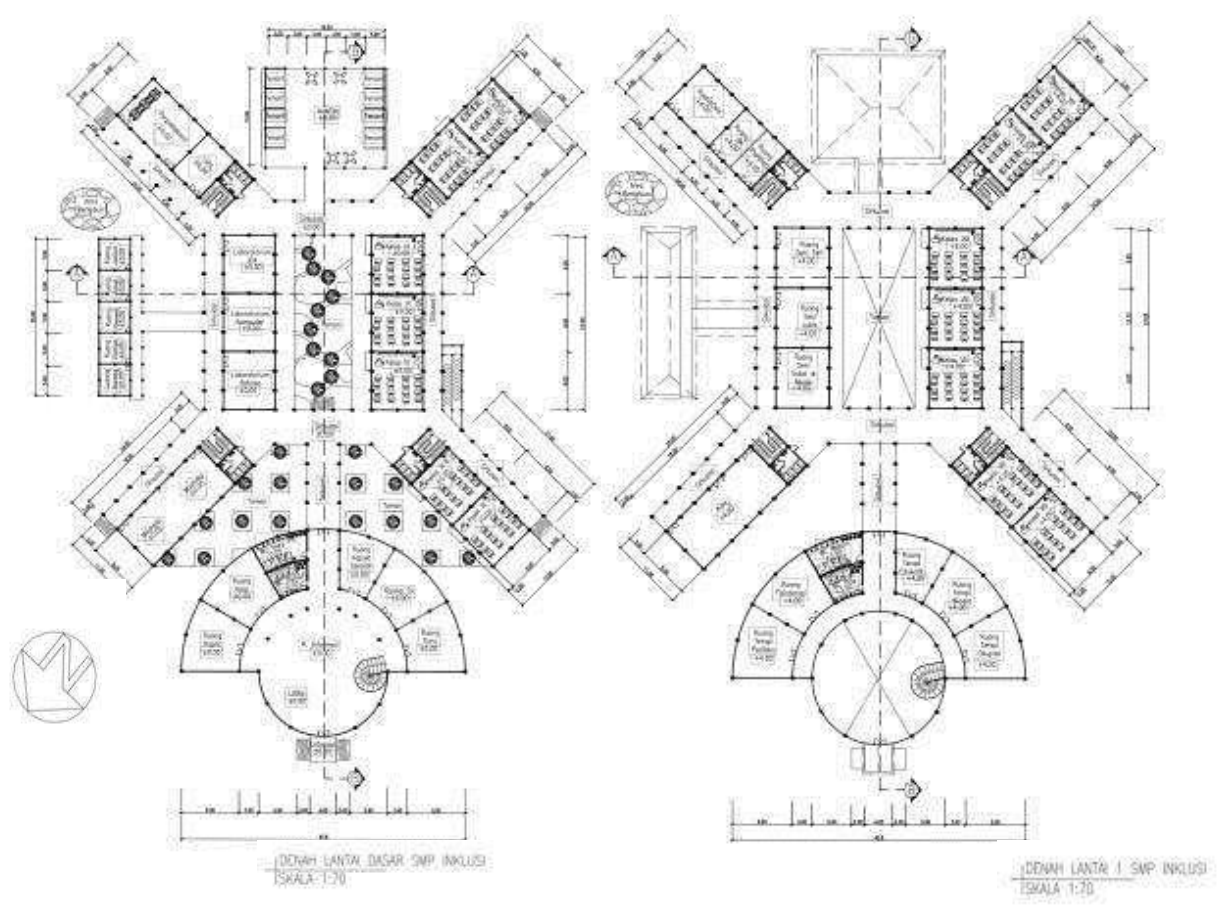



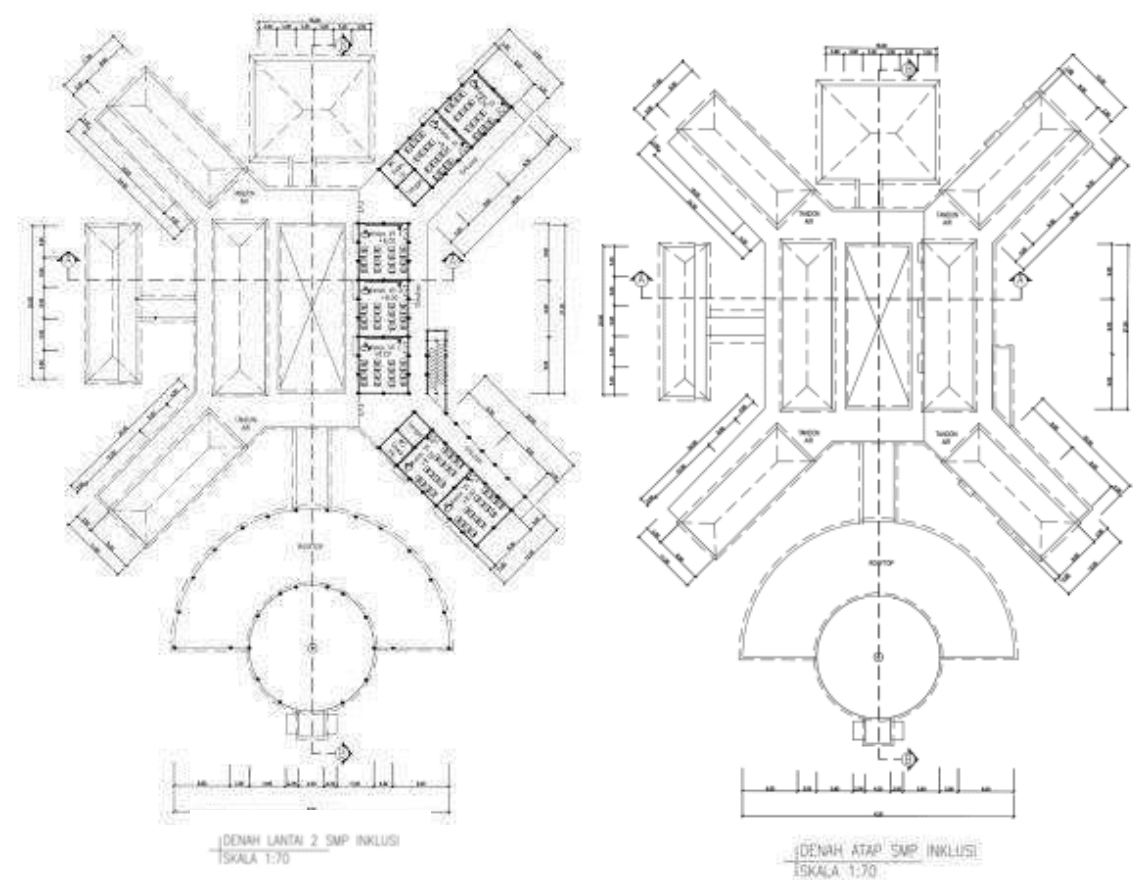

Gambar 13. Denah SMP Inklusi

Sumber: Penulis, 2021

Gambar 13 menampilkan denah lantai dasar, lantai satu, lantai dua, serta denah atap SMP Inklusi. Lantai dasar terdapat entrance, ruang kelas IXA - IXG, ruang kepsek, ruang guru, dan lainnya. Terdapat pusat informasi yaitu lobby, ruang informasi. Terdapat musholla, kantin ruang servis, UKS, perpustakaan, laboratorium, tangga, ramp, dan taman. Lantai satu terdapat ruang kelas VIIIA - VIIIG, ruang kesenian, ruang BK, ruang terapi okupasi, terapi wicara, fisioterapi, edukatif, perilaku, aula, WC, tangga, dan ramp. Lantai dua terdapat ruang kelas VIIA - VIIG, WC, tangga, ramp, ruang tandon air, serta rooftop. Denah atap menujunkkan bentuk atap yaitu atap prisma, serta ada ruang tandon air.

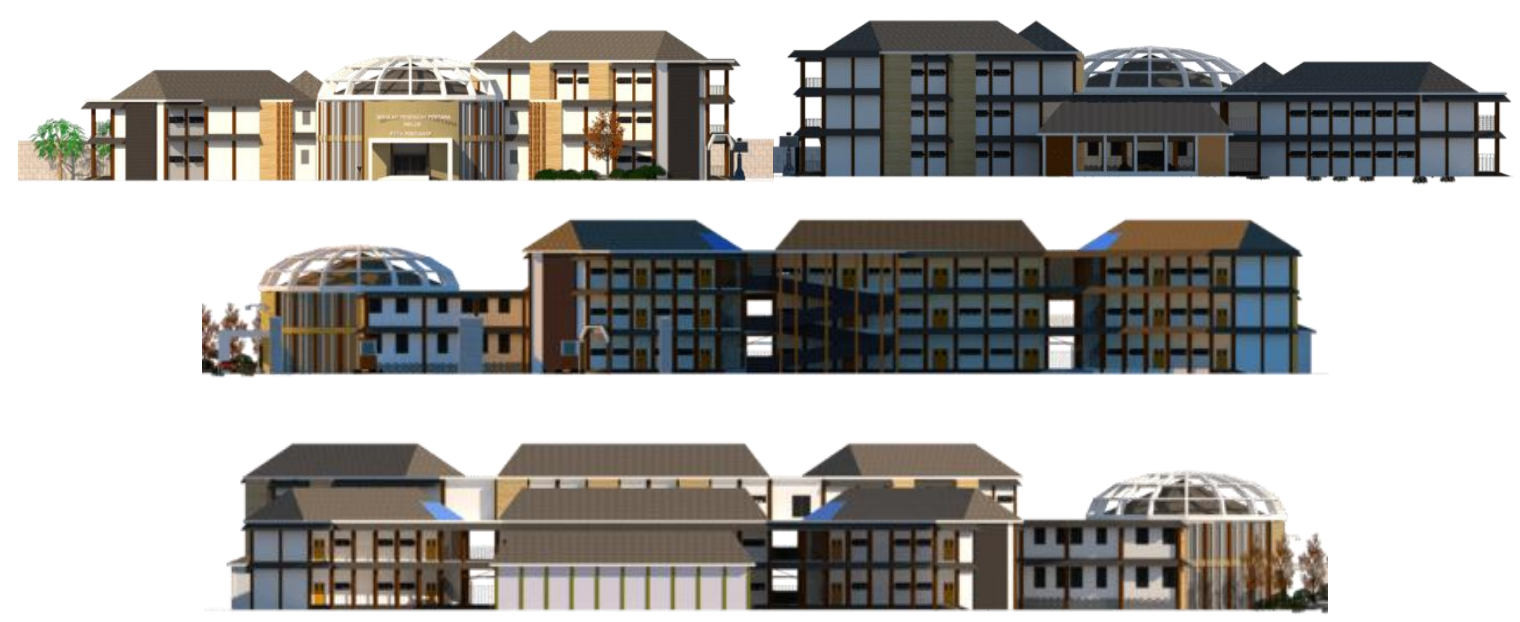

Gambar 14. Tampak Bangunan SMP Inklusi

Sumber: Penulis, 2021

Gambar 14 menampilkan tampak depan, belakang, kanan, dan kiri bangunan SMP Inklusi. Bangunan menggunakan dinding beton ringan dengan finishing cat putih agar memantulkan panas. Zona pengelola menggunakan material dinding tirai berupa kaca agar cahaya dapat mudah masuk ke 
dalam bangunan, penggunaan skylight pada bagian tangga agar memanfaatkan pencahayaan alami. Atap zona pengelola dibuat berbentuk kerucut dengan baja finishing putih sebagai point of view dari bangunan SMP Inklusi.

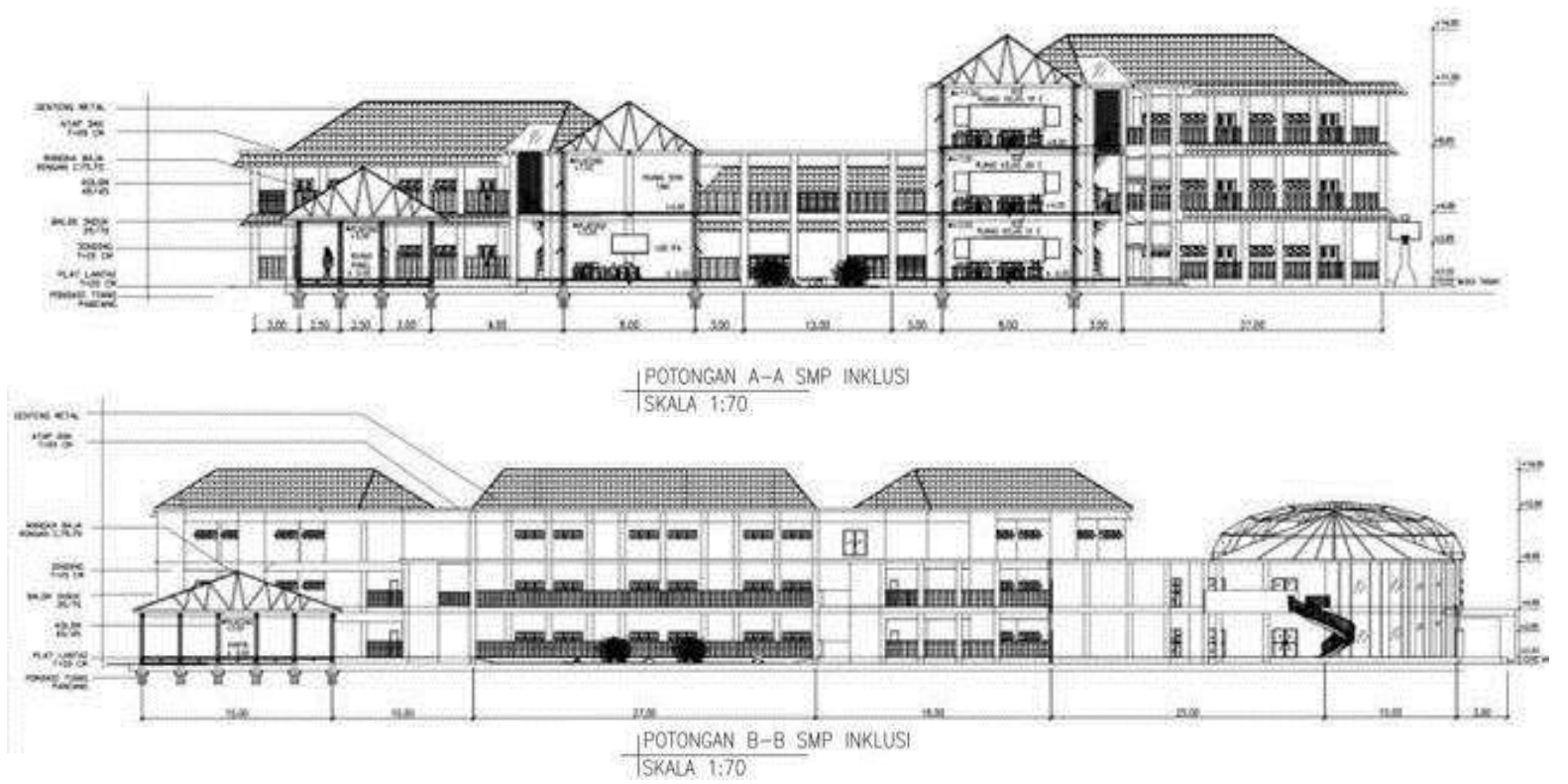

Gambar 15. Potongan Bangunan SMP Inklusi

Sumber: Penulis, 2021

Gambar 15 menampilkan potongan A - A dan B - B bangunan SMP Inklusi di Kota Pontianak. Sistem kerangka bangunan menggunakan sistem rigid frame dengan material kolom berasal dari beton komposit yang berbentuk bulat, agar mengurangi sudut pada bangunan. Kerangka atap menggunakan baja ringan karena dalam pengerjaan lebih cepat dibandingkan material lain. Penutup atap menggunakan genteng metal karena tahan api.

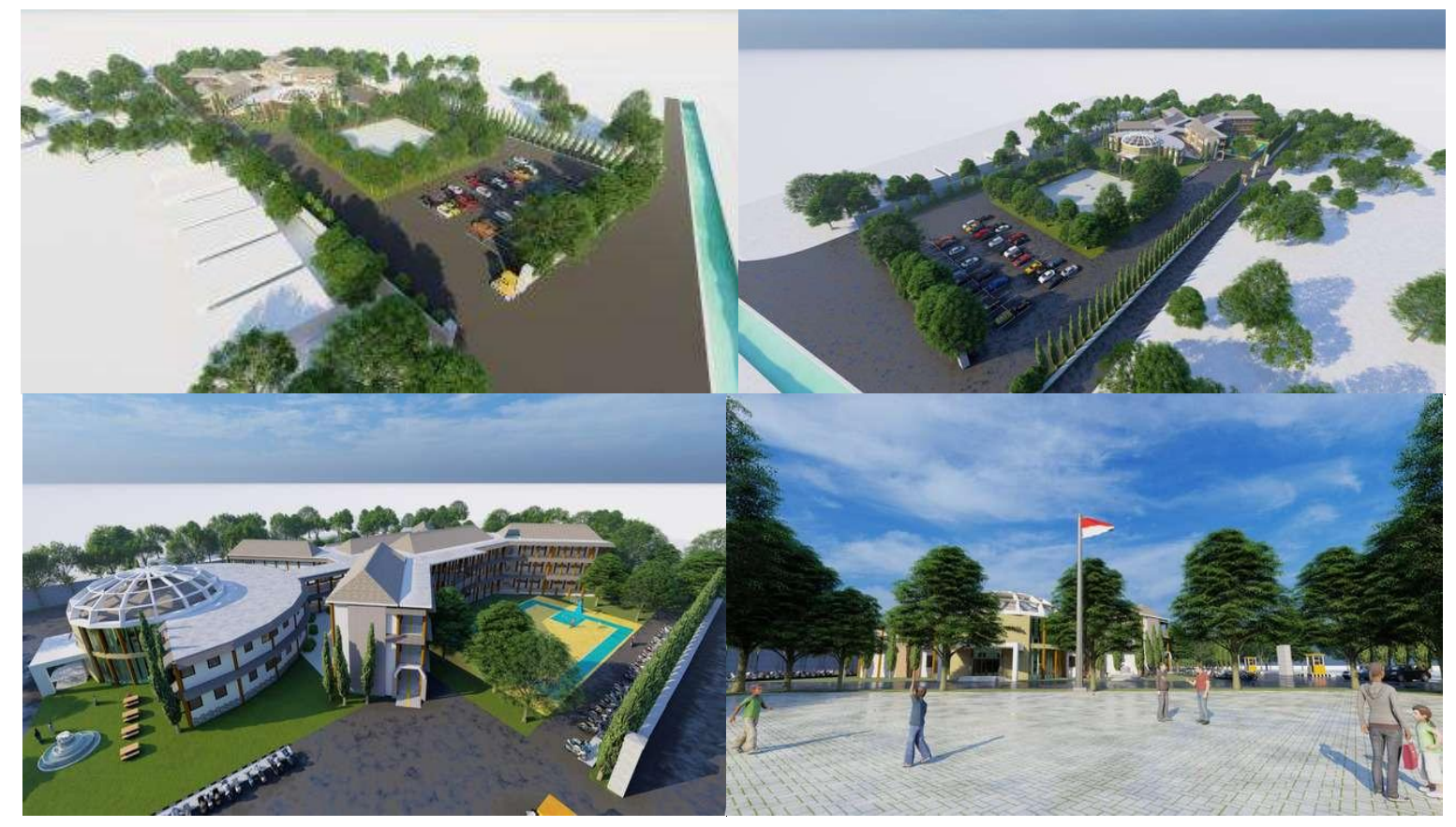




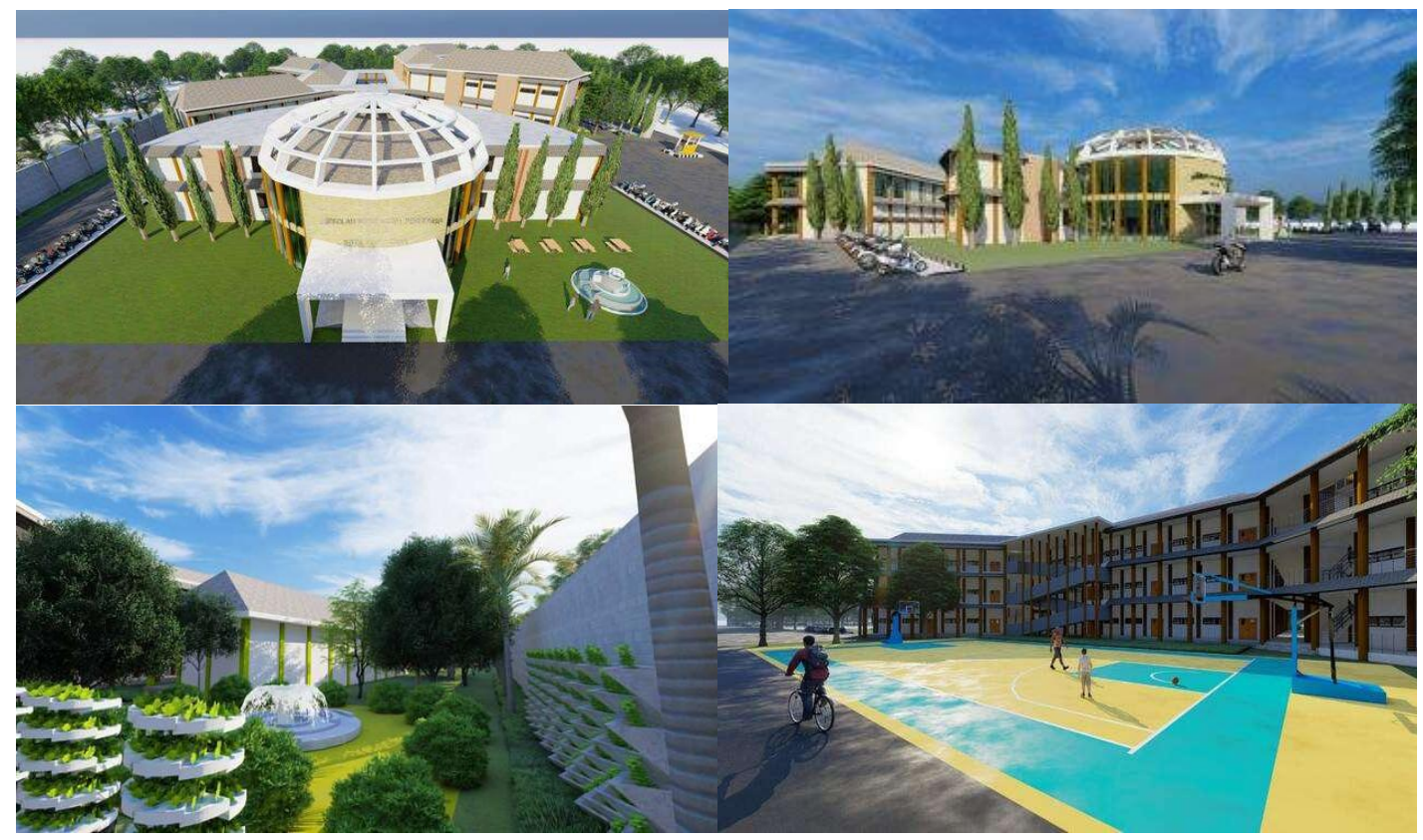

Gambar 16. Eksterior Bangunan

Sumber: Penulis, 2021

Gambar 16 menampilkan suasana eksterior Sekolah Menengah Pertama Inklusi di Kota Pontianak berupa view mata burung, lapangan upacara, lahan parkir, area berkebun, dan lapangan basket. Eksterior bangunan mengakomodir segala jenis kegiatan siswa di sekolah, akademik maupun keterampilan. Secara makro terdapat pedestrian di tepi bangunan yang dapat mengakomodir pejalan kaki, maupun siswa yang menggunakan kursi roda. Area berkebun, dan lapangan basket untuk mengasah keterampilan, meningkatkan kemampuan siswa yang bersekolah di SMP Inklusi.

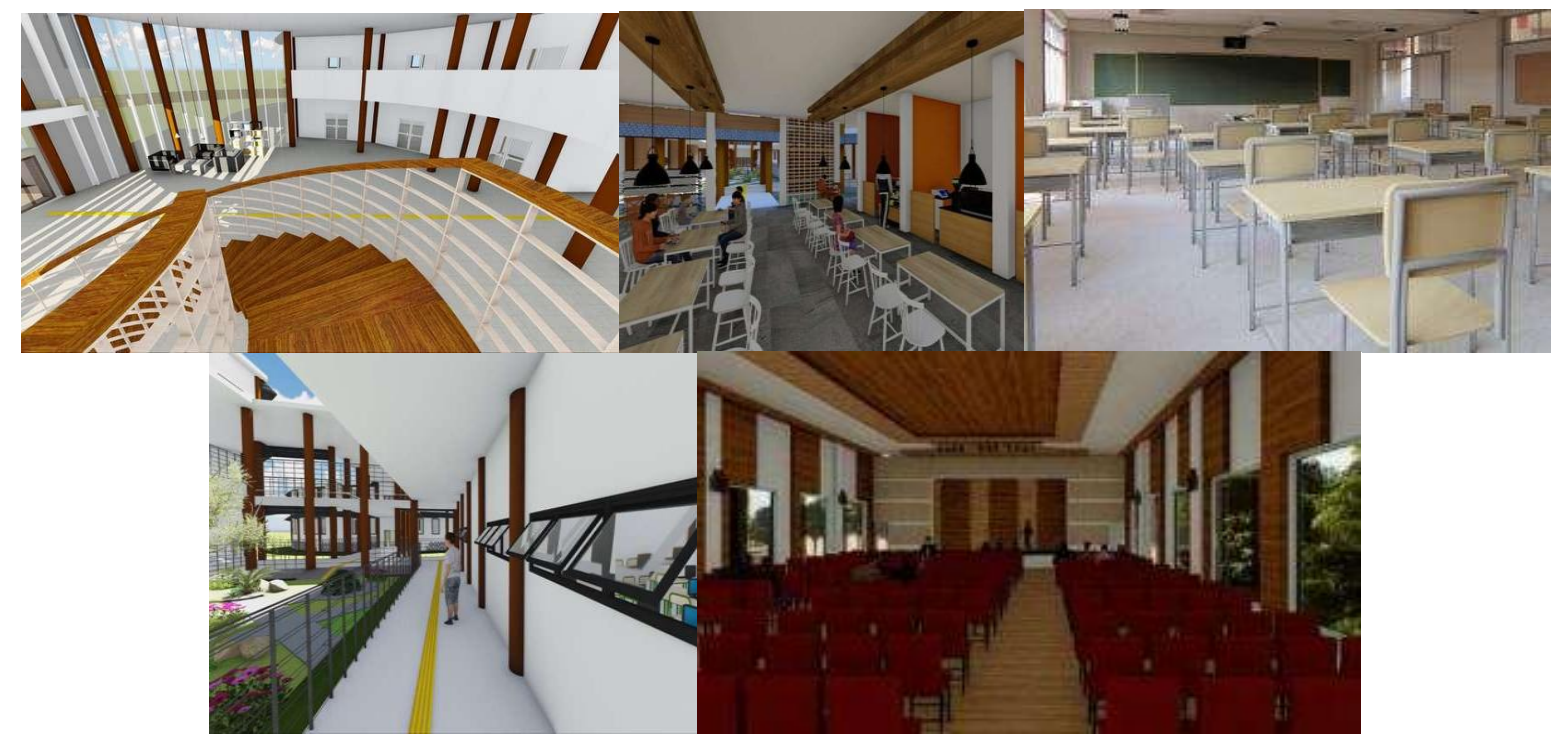

Gambar 17. Interior Bangunan

Sumber: Penulis, 2021

Gambar 17 menampilkan interior bangunan berupa lobby, kantin, kelas, koridor, serta aula pada bangunan SMP Inklusi. Ruang lobby diisi oleh perabot dan storage yang memfasilitasi pengunjung saat datang, dan menunggu untuk bertemu seseorang. Kantin tersedia 8 buah tenant yang berjualan di sekolah. Ruang kelas memiliki perabot yang sudah mengikuti standar sarana prasarana 
bangunan sekolah SMP. Koridor saling interkoneksi dan terdapat guiding block di setiap koridornya memudahkan akses bagi siswa yang berkebutuhan khusus.

\section{Kesimpulan}

Sekolah Menengah Pertama Inklusi merupakan wujud nyata dari pendidikan untuk semua yang mewadahi semua jenis kalangan siswa berusia 12 - 15 tahun baik yang reguler maupun siswa yang berkebutuhan khusus. Fasilitas yang mewadahi kegiatan di sekolah, baik secara makro maupun mikro. perancangan ini adalah berupa konsep yang diterapkan pada bangunan yang dapat merespon isu dan masalah yang terjadi mengenai sekolah bagi anak berkebutuhan khusus. Perancangan tata ruang luar direncanakan dapat mewadahi setiap anak dari adanya pencapaian dengan pedestrian dari parkiran menuju bangunan dengan guiding block bagi pengguna tuna netra, adanya akses ramp yang aman bagi penyadang tuna daksa menggunakan kursi roda maupun tongkat. Bentuk bangunan menyesuaikan dengan kebutuhan ruang, serta mengambil intisari dari filosofi "Dibalik Kekurangan Terdapat Kelebihan". Melihat kondisi tapak, desain dibuat merespon pepohonan eksisting. Bangunan dirancang ramping agar angin dapat dengan mudah masuk ke banguna. Bangunan ini juga tanggap terhadap bencana, dilengkapi dengan adanya assembly point bagian luar bangunan, akses tangga di setiap ujung sisi bangunan.

\section{Ucapan Terima Kasih}

Puji syukur kepada Allah Subhanahu Wa Ta'ala atas rahmat dan karunia-Nya tulisan ini dapat diselesaikan dan ucapan terima kasih kepada orang tua yang selalu mendukung, kepada para dosen yaitu Bapak Muhammad Ridha Alhamdani, S.T., M.Sc, selaku dosen pembimbing utama; Bapak Ir. Rudiyono, S.T., M.T., selaku dosen pembimbing pendamping; Bapak Dr. Techn. Zairin Zain, S.T., M.T., selaku Dosen Penguji Utama; dan Bapak Affrilyno, S.T., M.Sc., selaku Dosen Penguji Pendamping yang telah memberikan bimbingan, saran, motivasi, masukan dan kritik kepada penulis serta kepada pihak-pihak lain yang tidak dapat disebutkan satu persatu.

\section{Daftar Acuan}

Badan Standardisasi Nasional. (2004). SNI 03-1733-2004 Tata Cara Perencanaan Lingkungan Perumahan di Perkotaan. Jakarta: Badan Standardisasi Nasional

Badan Standardisasi Nasional. (2005). SNI 03-7065-2005 Tata Cara Perencanaan Sistem Plumbing. Jakarta: Badan Standardisasi Nasional

Hatmoko, A; dkk. (2014). Arsitektur Fasilitas Pendidikan. Yogyakarta: PT. Global Lancang Selaras

Jones, J. C. (1992). Design Method (Second Edition). New York: Van Nostrand Reinhold

Pusat Data dan Statistik Pendidikan dan Kebudayaan Kemendikbud RI. (2016). Gambaran Sekolah Inklusif Di Indonesia

(Tinjauan Sekolah Menengah Pertama). Jakarta: Pusat Data dan Statistik Pendidikan dan Kebudayaan Kemendikbud RI

Ramadhani, M. L. (2017). Desain Interior Sekolah Inklusi Galuh Handayani Surabaya yang Ramah Anak dengan Konsep Modern. Retrieved from http://repository.its.ac.id/43936/

Tarmansyah. (2007). Inklusi Pendidikan Untuk Semua. Jakarta: Depdiknas 